\title{
火力発電プラントにおける性能低下診断手法の開発*
}

\author{
高橋徹*1，幸田栄一*1，中尾吉 伸*1
}

\section{Development of Performance Deterioration Diagnosis Method for Thermal Power Generation Plants}

\author{
Toru TAKAHASHI ${ }^{* 2}$, Eiichi KODA and Yoshinobu NAKAO \\ ${ }^{* 2}$ Central Research Institute of Electric Power Industry, \\ 2-6-1 Nagasaka, Yokosuka-shi, Kanagawa, 240-0196 Japan
}

\begin{abstract}
It is necessary to maintain or improve the thermal efficiency in actual thermal power generation plants to reduce $\mathrm{CO}_{2}$ emission and energy consumption. And also it is important to decrease the maintenance cost in commercial plants. Thus, when the thermal efficiency decreases, it is crucials to identify the performance deterioration factors and solve the problems promptly by sufficient energy management. However, it is difficult to understand the internal state of the plants sufficiently and to determine performance deterioration factors only from operation data because actual thermal power generation plants are composed of many components and they are very complex systems. Therefore, we develop a method based on heat and mass balance analysis to calculate the immeasurable quantity of state and the component performance in the plants, and to correct the component performance to standard state using the performence function obtained from long-term operation data. Through the method, the analysis of the influence of deterioration factors on thermal efficiency becomes possible. As the results, we can determine the main factor that affects thermal efficiency deterioration using this method.
\end{abstract}

Key Words: Thermal Efficiency, Thermal Power Generation, Energy Management, Performance Deterioration, Heat and Mass Balance Analysis

\begin{abstract}
1. 緒言
二酸化炭素排出量とエネルギー消費量の増咑制あるい は消䁍のために，既存の火力発電プラントにおいては，そ の熱効率を維持，向上することが重要である. また，熱効 率汃泜下した場合，その要因を早急に解明し対策を講じる ことができれば，熱效率の維持・向上だけでなく，メンテ ナンスコスト低減にもつながる. そのためには，熱効率の 低下要因を解明する手法が必要である.

現在の火力発電プラントに和いては，損失法や入出熱然 による熱效率管理か行われておりり(2)，プラント全体の熱 効率を示すプラント熱効率の他、汽力発電プラントに拟、 ては，ボイラ効率柿よびタービン室熱効率，また，ガスタ ービン複合サイクル (GTCC) 発電プラントにおいては, ガスタービン室效率，蒸気タービン室效率，排熱可収ボイ ラ効率といらた指標が用いられている. しかしながら，発 電プラントを構成する機器の数が多いため,プラント熱効
\end{abstract}

\footnotetext{
* 原稿受付 2010 年 5 月 18 日。
}

*1 正員, (財) 電力中央研究所 (画 240-0196 横須賀市長坂 2-61).

E-mail : toru-tak@criepi.denken.or.jp
率方泜下した場合，これらの方法および指標で灶その低下 要因を特定することが困難である. また，これらの指標恃， 大気条件，海水温度などの外的条件により変動することか ら，十分な性能管理に使用すること力灘しい，

一方，筆者らは，これまで発電システムの熱物質収 支解析を汎用的に行うことができる手法を開発し ${ }^{(3)}$, また，その手法をプログラム化し，グラフィックュー ザーインターフェースを用いたソフトウェアを開発し てきた(4).ささらに，それら手法，ツールを用いて，主 に新型発電システムの開発における熱効率解析，比較 評価および最適化などを行ってきた(5)(の).

この解析技術を応用して，既設の火力発電プラント について，その運転データを用いた熱物質収支解析に より，プラント内の計測が困難な简所の状態量や構成 機器の性能などを算出することで熱効率影響因子を把 握し，さらに,外的条件変化の影響を排除した上で個々 の因子が熱効率に与える影響を定量化することにより， 熱効率低下要因の解明を行う手法を開発した. 本報で は，その手法ならびに実火力発電プラントに適用した 事例を示す。 


\section{2. 現状の熱交率管理の問題点之 熱效車低下診断手法の開発}

2.1 現状の熱效率管理の問題点 事業用汽力発電 プラントは，図 1 に示すように，一般に高圧タービン (HPT)，中圧タービン (IPT)，低圧タービン (LPT) などの蒸気タービン (ST) の他, 給水加熱器 (FWH), ポンプ, 各種等交換器, 復水器など数多くの機器で構 成されている. 現在の火力発電プラントにおいては, 損失法や入出熱法による熱効率管理が行われており， 汽力発電プラントにおける熱効率の性能指標としては, (1)式で定義されプラント全体の熱効率を示すプラン 卜熱効率 $\eta_{p}$ の他，(2)式で定義され蒸気タービン系 (主 に蒸気タービン, 給水加熱器, 復水器等で構成される, ボイラ以外の蒸気系統全体）の熱効率を示すタービン 室熱効率 $\eta_{t},(3)$ 式で定義されボイラの熱効率を示すボ イラ效率 $\eta_{b}$ のみが用いられている.ここで, $P$ は発電 出力, $H_{l}$ は然料発熱量, $Q$ は空気およひ燃料顕熱, $Q_{s}$ はボイラでの有効出熱， $L_{I}$ はボイラにおける損失合計 である. さらに， $m_{j}$ はボイラにおける給水または点気 の流量, $\Delta h_{j}$ はボイラ各部における水, 蒸気の熱量変 化を示寸.

$$
\begin{aligned}
& \eta_{p}=\frac{P}{H_{l}+Q} \\
& \eta_{t}=\frac{P}{\sum\left(m_{j} \Delta h_{j}\right)}=\frac{P}{Q_{s}} \\
& \eta_{b}=\frac{Q_{s}}{H_{l}+Q} \text { または } \quad \eta_{b}=1-\frac{L_{l}}{H_{l}+Q}
\end{aligned}
$$

したがって, (1)から(3)式の間には, (4)式に示す関係 が成り立つ。

$$
\eta_{p}=\eta_{b} \times \eta_{t}
$$

以上の式から分かるように，これら指標は，プラン 卜全体，ボイラあるいは蒸気タービン系の性能を示す ものであり，したがって，プラント熱効率が低下した 場合, その原因がボイラ側か凄気タービン系側か判別 することは出来るが，汽力発電プラントを構成する数 多くの機器のどの機器であるかを特定することは困難 となっている.

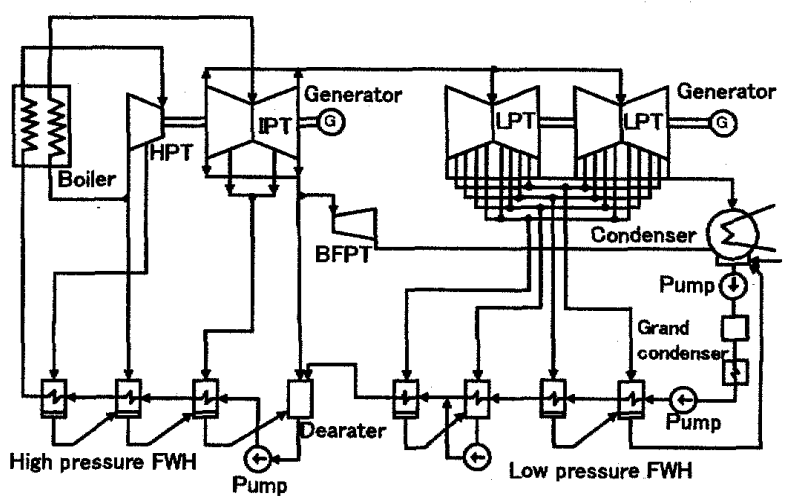

Fig. 1 Schematic diagram of a steam power plant ${ }^{(7)}$

また，事業用 GTCC 発電プラントは，図 2 に示すよ うに，圧縮機 (COMP)，ガスタービン (GT)，高圧 タービン，中低圧タービン（IIPT）の他，排熱回収ボ イラ (HRSG) における多くの伝熱面などで構成され ている. その熱効率の性能指標としては，プラント熱 効率の他，(5)式で定義されガスタービン系（主に圧縮 機，燃焼器，ガスタービンで構成される系）の熱効率

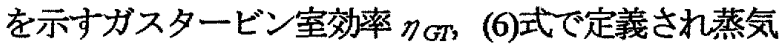
タービン系の熱効率を示寸蒸気タービン室熱効率 $\eta_{S T}$, (7)式で定義され排熱回収ボイラの熱効率を示すHRSG 効率 $\eta_{H R S G}$ といった指標が用いられている.

$$
\begin{aligned}
& \eta_{a r}=\frac{P_{\sigma T}}{H_{l}+Q}=1-\frac{Q_{g a s}}{H_{l}+Q} \\
& \eta_{s T}=\frac{P_{S T}}{\sum\left(m_{j} \Delta h_{j}\right)}=\frac{P_{S T}}{Q_{s}} \\
& \eta_{H R S a}=\frac{\sum\left(m_{j} \Delta h_{j}\right)}{Q_{g a s}}=\frac{Q_{s}}{Q_{g a s}}
\end{aligned}
$$

ここで， $Q_{\text {gas }}$ はガスタービンの排ガス顕熱を示し， $P_{G T}, P_{S T}$ はガスタービン系と蒸気タービン系それぞれ の発電出力を示す. $P_{G T}, P_{S T}$ は(8)式の関係があるため, (5)から(7)式の間には(9)式に示寸関係が成り立つ.

$$
\begin{aligned}
& P=P_{G T}+P_{S T} \\
& \eta_{P}=\left(1-\eta_{G r}\right) \times \eta_{S T} \times \eta_{\text {RRSG }}+\eta_{G T}
\end{aligned}
$$

これら式から分かるように，汽力発電プラントと同 様, プラント熱効率が低下した場合，これら指標のみ ではその原因がガスタービン采側か, 蒸気タービン系 
側かあるいは排熱回収ボイラ側かを判別することは出 来るが，その原因が数多くの機器の中のどの機器であ るかを特定することは困難である。

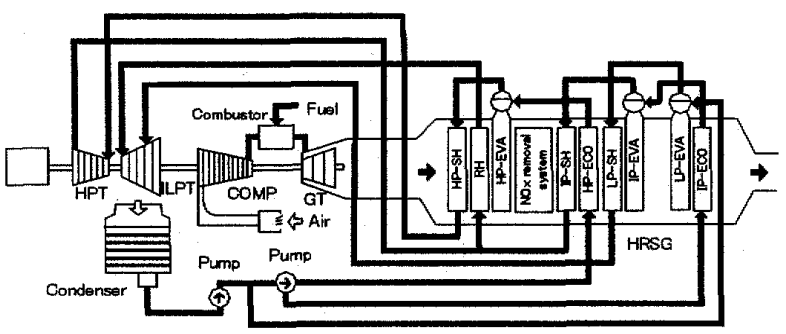

Fig. 2 Schematic diagram of a GTCC power plant ${ }^{(8)}$

また，一軸型の GTCC の場合，ガスタービン系と蒸 気タービン系それぞれの発電出力 $P_{G T}, P_{S T}$ を個別に把 握することは困難である. 梅沢(9)によるトルクセンサ を用いた新たな方法も考案されているが，現状，給水 流量や吸込空気流量などの関数からそれぞれの発電出 力を算出することが一般的であり，プラントの性能が 変化した場合, 実際のそれぞれの発電出力は変化する にも拘らず，計算値は変化しないため，上式による各 効率算出值が実態と異なる可能性がある.

さらに，上記の指標は，大気条件，海水温などの外 的条件により大きく変動することから，これらによる 十分な性能管理が難しいものとなっている. また，構 成する機器の性能值がそれら外的条件により変化した 場合, 機器自体の性能変化も把握しづらいものとなる.

$2 \cdot 2$ 熱効本低下診断手法の開発 前節で示した 問題点から，火力発電プラントにおける熱効率低下要 因を解明するための手法を検討し，以下を考案した.

\section{(1) 実測值基淮解析}

火力発電プラントにおいて, 個々の機器の性能指標, たとえげ圧縮機，ガスタービン，各蒸気タービンなど 回転機器では断熱効率, 各給水加熱器ではそれぞれの 端末温度差や初温度差，排熱回収ボイラの各伝熱面に ついては熱貫流率などを把握できれば，プラント熱効 率が低下した場合，その原因がどこにあるのか推測で きると考える.

これらの性能指標を算出するためには機器出入口 作動流体の状態量が必要となるが，計測が困難なもの がある. たとえば，低圧タービン出口の蒸気は一部湿 り域に入ってしまい，温度，圧力の計測值ではその湿 り度を把握できず，したがって，その作動流体のエン タルピが不明であるため，計測值から直接断熱効率を 算出することはできない．また，ガスタービンにおい ては，燃焼温度が高温となるため直接温度を計測する
ことが難しく，燃焼温度を把握するためには燃料およ び圧縮空気による燃焼計算を行う必要がある.そこで， 計測されている運転データから熱物質収支解析（以下， 実測值基淮解析と記す）を行うことにより，計測でき ない部分の状態量を算出し，それらにより各機器の性 能值を算出することが可能となる.

また，一定負荷で静定された場合でも，プラント内 部は流れの乱れ，外乱等により常に変動しており状態 は必ずしも一定ではなく, 計測値にも誤差を含むため, ある瞬時值での比較では正しい性能評価が行えない可 能性がある．したがって，長期間にわたり短間隔で収 録された膨大なデータを処理することにより，ある程 度の幅を持つものの, 各機器性能値の経年的な変化傾 向を把握できると考える.

(2) 機器性能值の標準状態換算

機器の性能において，定格出力時であっても，大気 条件, 海水温などの外的条件により変化する場合があ る. そこで, 機器入口の作動流体の状態量を独立変数 とする機器性能関数を作成し，この関数の独立変数を 標淮の值（以下，標準条件と記す）とすることで，標 準条件での機器性能值（以下，標準状態と記す）に換 算できる.これによって, 同一の条件下での比較が可 能となると考える.

図 3 に, 機器性能関数の概念を示す. 運転開始 1 年

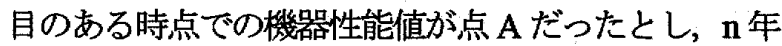
目のある時点での值が点 B だったとする. 值自体は同 程度であるが，作動流体の状態が全く異なっている.

そこで，長期間の運転データから算出された多数の 機器性能值から，最小二乗法などにより関数の傾きを 求め，その傾きをもつ関数が点 $\mathrm{A} ， \mathrm{~B}$ それぞれ通るよ うに定数項を求めることによって，それぞれの点を通 る性能関数を求めることができる. それら関数に，標 準条件を入力することにより機器性能值を標準状態に 換算でき，それら差を性能変化として求めることがで きると考える.

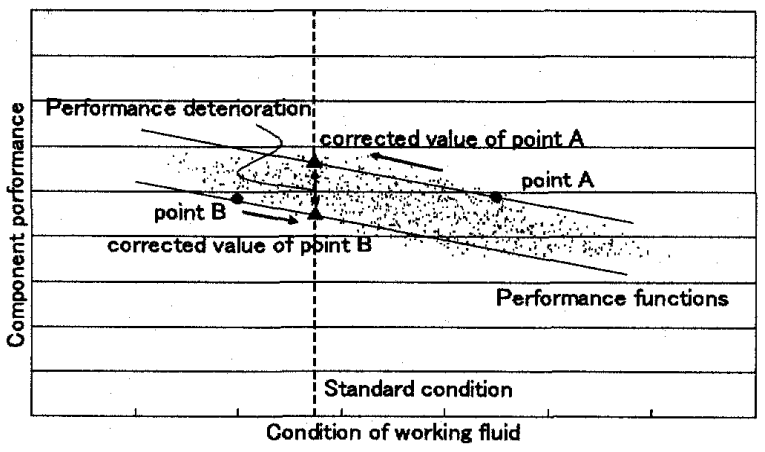

Fig. 3 Concept of the performance function 


\section{(3)機器性能基淮解析}

以上により機器性能值力算出され，さらに標蕉状態 への換算により，同一条件下での機器性能値の比較評 価が可能となる.しかしながら，機器によってその性 能指標は異なっており，またそれぞれの機器性能值の 変化がプラント熱効率に与える影響は異なる.したが って，性能が最も大きく低下した機器が必ずしもプラ ント熱効率の低下を招いている最大の原因とは限らな い.たとえば, 汽力発電プラントにおいて高圧, 中圧, 低圧タービンそれぞれの断熱効率が 1\%低下した場合, それぞれのタービン出力が巽なるため，プラント熱効 率に与える影響は異なる．したがって，個別の機器性 能值を把握するだけで注，プラント熱効率低下の主要 因の特定には至らない.

そこで，実測值基準解析かっら得られた個々の機器性 能値, さらに標準状態への换算で得られた機器性能值 を用いて熱物質収支解析（以下，機器性能基淮解析と 記す) を行い，その個々の機器性能值の変化がプラン 卜熱効率に与える影響を定量的に解析することで， ど の機器の性能変化がプラント熱効率の低下に最も関与 しているかが解析できるものと考える.

\section{(4)解析手順}

以上の解析手法の手順娄 4 のフロ一図に示寸. 主な内 容は以下の通りである。

i. 対象プラントの熱物筫解析モデルを作成し, データ入力 点を計湘点と一致させる.

ii 計画のヒートバランスと対比し，作成した熱物質解析モ デルの妥当性在検証する.

iii. 長期間の運転データを用いて熱物質解析モデルにより 実測値基淮解析を行，その結果からら各機器性能值の経 年変化を把握する。

iv. 同一条件での比較のため, 機絽姓能関数を作成し機器性 能值の標潗状態への換算を行う.

v. 任意の時期のプラント熱効率と各機器性能值, たとえば 運䡛開台時と数年経った現在での值を比較し，それらの 変化量を得る.

vi. 機器性能基淮解析を行，それぞれの機器姓能值の変化 量がプラント熱効辩に与える影響を個別に解析する。

vii. それらの結果からプラント熱效率の低下に最も影響し ている因子老特定する.

以上の上うにそれぞれの因子がプラント熱胶率に与える 影響を定星的に把握することにより，それらを改善した場 合の経済評価も可能になる，つまり，機器を改善するため の修繥コストと，機器を改善しプラント熱効率か回復また 仕向上した場合の然料費低減分を比較することにより，最 も費用対効果の高い因子を決定することができると考える.

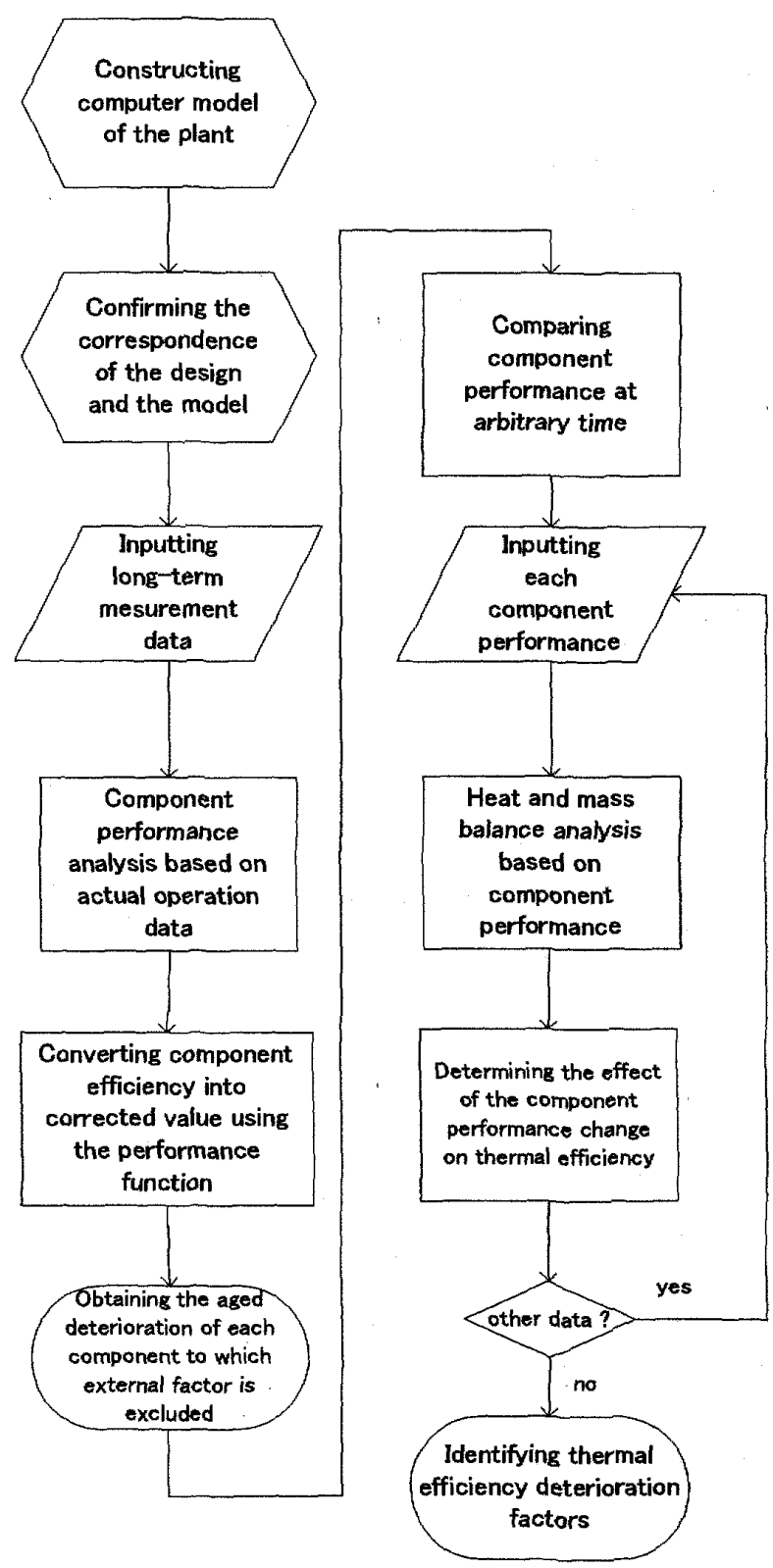

Fig. 4 The procedure to analyze performance deterioration factors

\section{3. 既殷火力発電プラントの解析結果}

3.1 汽力戣電プラントの解析 近 3 年間でプラント 熱効率こ低下が見られた既存の1000MW級气力発電プラン トにつて本手法を適用し，その要因解析を行った

プラントは常に変動しているため，デー夕点数か短期間 の少量のものである場合には，機器性能值等の変化がその 変動の幅こ入っている可能性がある. そこで, 3 年間の定格 出力時 1 時間每の運䡛データを用いて実測值基隻解析を行 い，各機器性能值の変化を調へた，その一例として，図 5 に高圧タービー断熱效率の経年変化を示寸。この図加ら， 
定格出力での高圧タービン䛧熱效率においては季節変化に よる変化は見られず，また定期点検時こおいて回復が見ら れるものの，長期間にわたっては経年的に低下しているこ とがわかる.

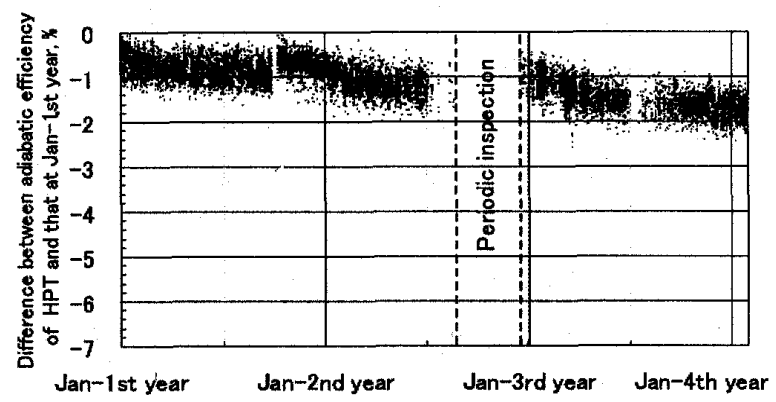

Fig. 5 Secular change of adiabatic efficiency of HPT

図6に復水器真空度の経年変化を示す.図が示すように 復水器真空度は夏季に低く冬季に高くなる傾向が見られ， 季節変化の影響を強く受けることが分かる. したがって， 復水器自体の性能変化を把握するためには，この季節の変 化，つまり泠却海水温度の変化の影響を除外して比較する 必要がある。

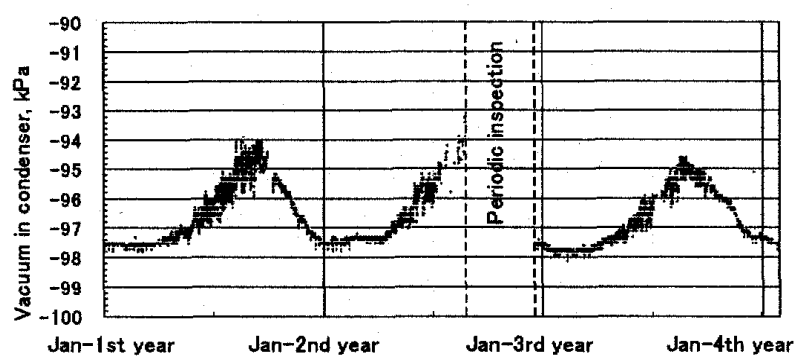

Fig. 6 Secular change of vacuum in the condenser

そこで, 復水器真空度の冷却海水温度に対する依存 性を調べた．その結果を図7に示す．図が示すように 復水器真空度は冷却海水温度に対し強い依存性を示寸 ことがわかる。

2.2 節(2)で示した方法により, 復水器真空度の標準 状態への換算を行った. 真空度 $P_{v}$ の図中における各点 での泠却海水温度 $t_{w}$ に対する性能関数を作成した. 図 の長期間多点数のデータから最小二乗法により，それ ぞれの性能関数の二次項および一次項が得られ，下式 が得られる.

$$
P_{v}=8.44 * 10^{-3} t_{w}{ }^{2}+6.22 * 10^{-2} t_{w}+c 0
$$

さらに 各点の性能関数の定数項 $C 0$ は，各点を通るよう に上式を平行移動させることにより，つまり，各 $\mathrm{x} ＼textrm{y}$ 軸の 值を代入することにより得ることが出来る. 以上て得られ た各点の機器性能関数に, 標準の椧却海水温度を代入する ことにより，補正された真空度が得られる。

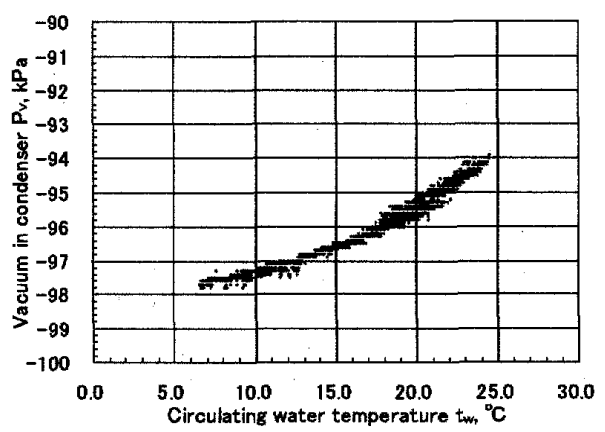

Fig. 7 Relation between vacuum in condenser and circulating water temperature

以上の方法により標準の泠却海水温度に換算した 真空度の経年変化を図 8 に示す，図が示すように，図 6で見られた季節変化による性能の変化を排除でき， 復水器自体の性能変化が把握できた. その結果, 定期 点検前までに真空度が低下しており性能低下が見られ るが, 定期点検時の洗浄による性能向上が認められた. しかし，その後徐々に性能が低下して行き，初年と 3 年後ではほぼ同程度となっていることが分かった。

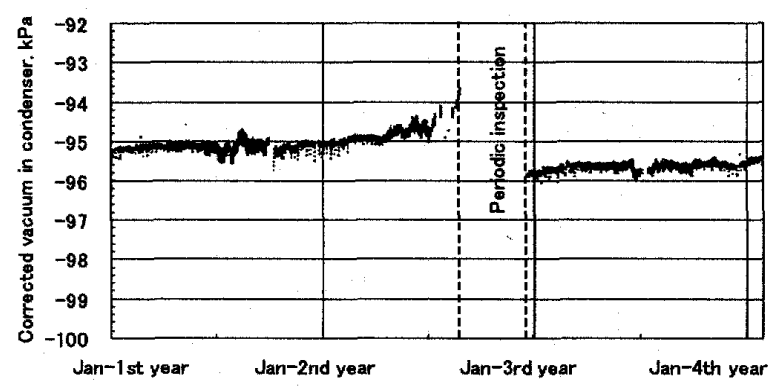

Fig. 8 Secular change of corrected vacuum in condenser

以上のように，実測值基淮解析から得られた各機器の性 能值，また，主蒸気や再熱蒸気温度などプラント熱効率に 大きく影響する主要な状態量について, 3 年間での変化を比 較した 各タービンの楼熱効率の変化を図9に，給水加熱 器性能旨標として端末温度差 (T.TD) およひ初温度差

(ITD) の変化を図 10 に示す。これら図から，特に高圧夕 一ビンおよひ第 $1 \mathrm{~A}$ 高王給水加熱器（1A-FWH）におい 性能低下か㵔しいことが分かかた 一方，中圧タービン， 第6 給水力熱器 (6-FWH) なと熱効率を向上している因子 
もあることが分かった その他，主蒸気管およひ再熱蒸気 管の熱損失の上昇, 主蒸気圧力の低下，低圧給水加熱器入 口温度の低下，ボイラ入口給水配管の熱損失の低下，ボイ ラ給水ポンプタービン (BFPT) の駆動用蒸気流量の増力な ど，熱効辩低下因子が見られた。

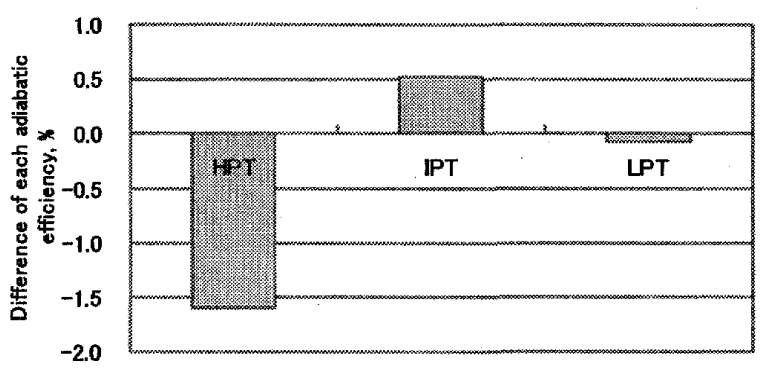

Fig. 9 Difference of adiabatic efficiency of each steam turbine for 3 years

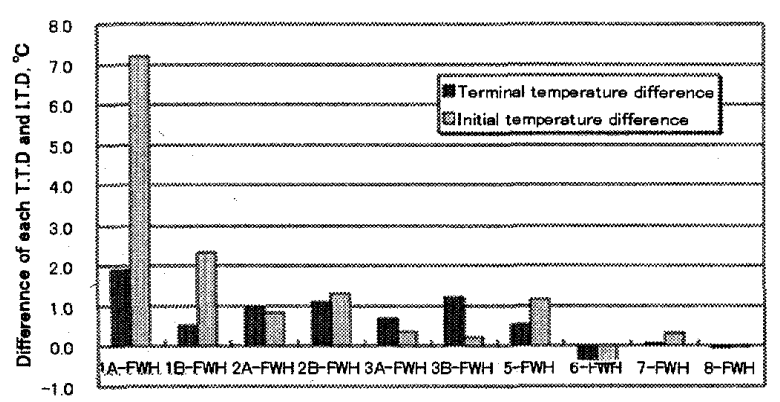

Fig. 10 Difference of terminal temperature difference (T.T.D) and initial temperature difference (I.T.D) of each feed water heater for 3 years

以上から，本汽力発電プラントに対して，実測值基 準解析により，プラント熱効率の変化に影響を与えて いる因子を挙げることができた.

しかしながら，機器によってその性能指標が異なり， また同じ種類の機器，つまり，同じ性能指標であって も，プラント熱効率に与える影響は異なる.

そこで，実測值基準解析により得られた影響因子か ら機器性能基準解析を行い，それらの因子がプラント 熱効率に与える影響を定量的に解析し，プラント熱効 率低下の主要因を特定した，その結果を図 11 に示す。 機器性能としては給水加熱器の性能の低下が見られた が，この図から，プラント熱効率に与える影響は小さ いことがわかる（なお，それぞれの給水加熱器の性能 低下による熱効率への影響は微小であったため，ひと つのグラフに組めた），全ての影響因子の中で最もプ ラント熱効率低下に影響を与えている因子は，高圧夕 ービン断熱効率の低下であることわかった.

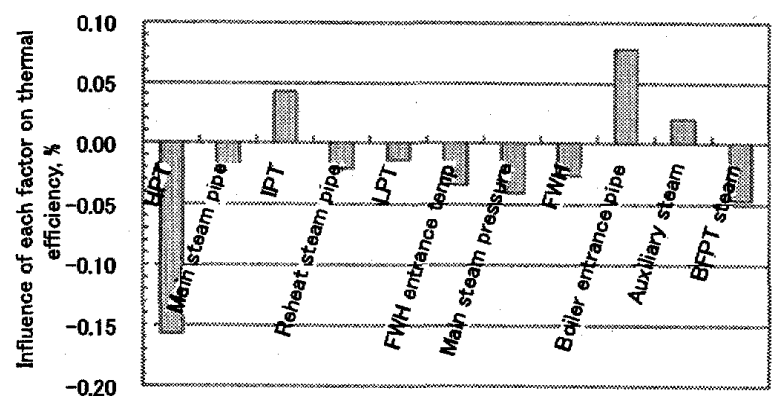

Fig. 11 Influence of each factor on thermal efficiency

3-2 GTCC 発電プラントの解析 近 4 年間でプ ラント熱効率に低下が見られた既設の $250 \mathrm{MW}$ 級一軸 型の GTCC 発電プラントについて, 開発手法を適用し た事例を以下に示す。

長期間の運転データにより実測值基淮解析を行い, 機器性能値の変化を調べた．なお，解析のための運転 データとしては，圧縮機での吸込空気体積流量が一定 となるよう圧縮機入口翼開度が全開付近の 1 時間毎の データを抽出した.

圧縮機断熱効率および圧力比の経年変化をそれぞ れ図 12，13に示す. 図が示すように，GTCC 発電プラ ントにおいては, 復水器真空度だけでなく, 圧縮機断 熱効率および圧力比も季節変化の影響を受けることが わかる. 圧縮機断熱効率は夏季に高く冬季に低くなり， 圧力比は夏季に低く冬季に高くなっている．したがっ て，圧縮機自体の性能変化を把握するためには，この 季節の変化つまり大気条件の変化の影響を除外する必 要がある.

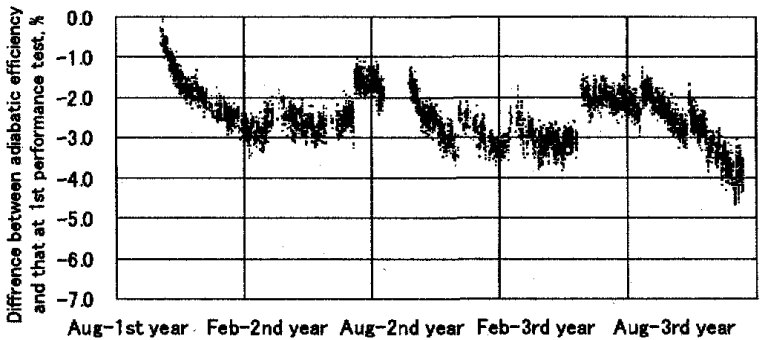

Fig. 12 Secular change of adiabatic efficiency of compressor

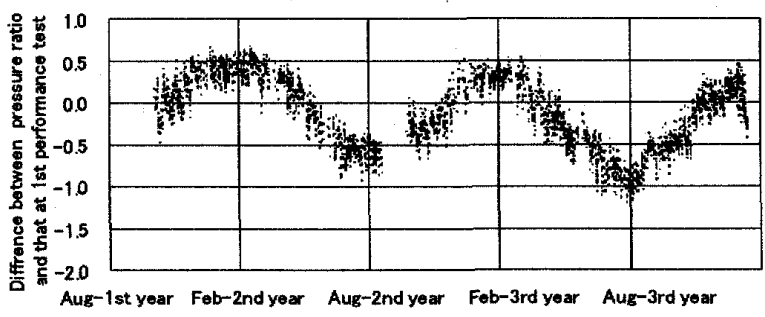

Fig. 13 Secular change of pressure ratio of compressor 
大気条件，つまり大気温度，大気圧，湿度の変化に よって空気密度が変化するため, 吸込空気体積流量一 定の条件下では，吸込空気重量流量が変化する. そこ で，圧縮機断熱効率および圧力比の吸込空気重量流量 に対する依存性を調べた。 それらの結果を図 14，15 に示寸．これらの図が示すように，王縮機断熱効率お よび圧力比は吸込空気重量流量に対し強い依存性を示 すことがわかる.

これらについても，2.2節(2)で示した方法により標 淮状態への換算を行った．図中における縮機断熱効

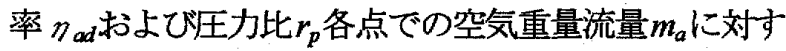
る性能関数を作成した. 各図の長期間多点数のデータ から最小二乗法により，それぞれの性能関数の二次項 およびー次項が得られ，下式が得られる。

$$
\begin{aligned}
& \eta_{a d}=-3.98 * 10^{-4} m_{a}{ }^{2}+3.02 * 10^{-1} m_{a}+c 1 \\
& r_{p}=1.13 * 10^{-5} m_{a}{ }^{2}+1.74 * 10^{-2} m_{a}+c 2
\end{aligned}
$$

さらに, 各点の性能関数の定数項 $c 1, c 2$ は, 各点を 通るように上式を平行移動させることにより，つまり， $\mathrm{x} ， \mathrm{y}$ 軸の值を代入することにより得ることが出来る. 以上で得られた各点の性能関数に，標準大気の重量流 量を代入することにより，補正された圧縮機断熱効率 および圧力比が得られる。

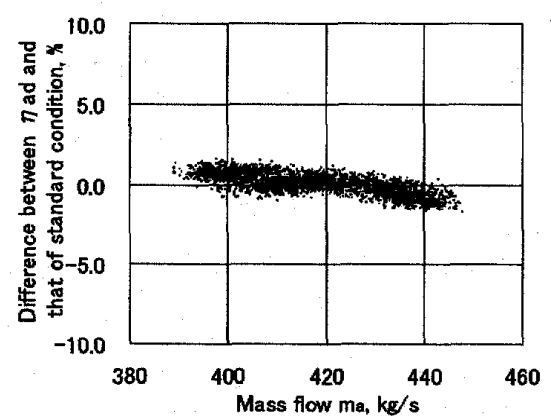

Fig. 14 Relation between adiabatic efficiency and mass flow

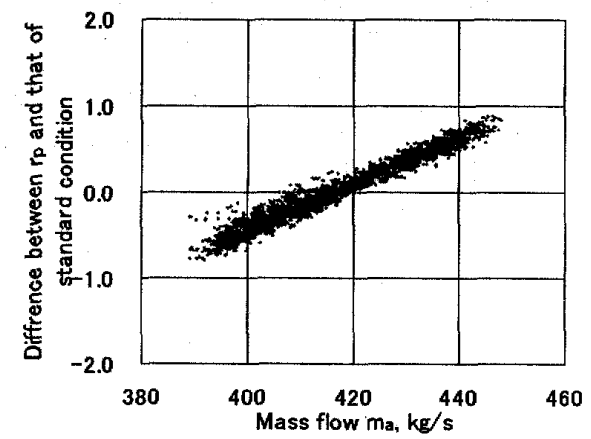

Fig. 15 Relation between pressure ratio and mass flow
以上の方法により標準大気条件に換算した断熱効 率および圧力比の経年変化をそれぞれ図 16,17に示す。 これら図が示すように, 図 12,13 に見られた季節変化 による性能の変化を除外でき, 压縮機自体の性能変化 が把握できた. その結果, 翼洗浄, 定期点検により， 断熱効率および圧力比注向上するものの, 経年的には 当初に比べ性能が低下していることがわがた.

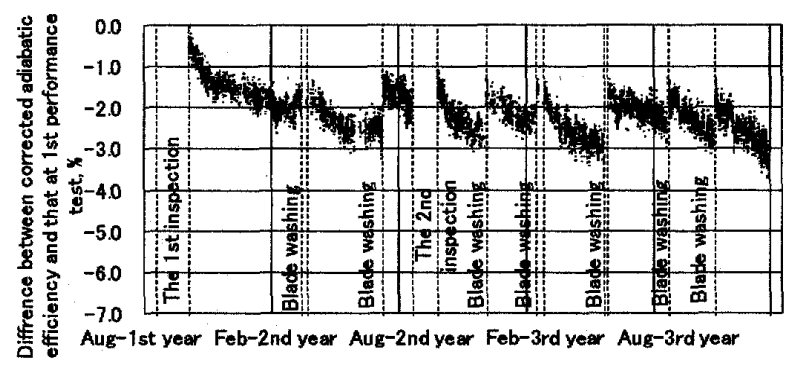

Fig. 16 Secular change of corrected adiabatic efficiency of compressor

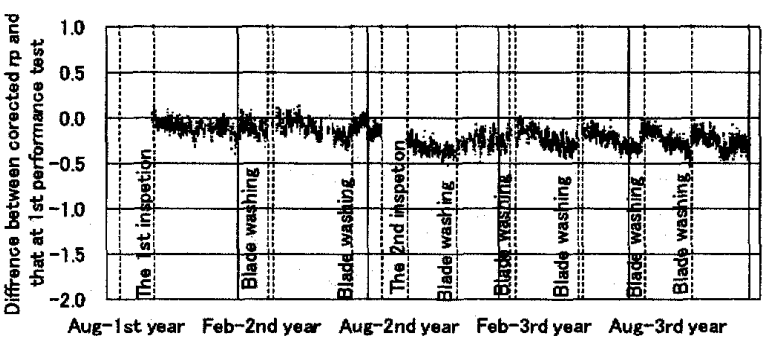

Fig. 17 Secular change of corrected pressure ratio

4 年間の各機器の性能值を比較した結果を図 18，19 に示す(なお，図 19 中の HP, IP, LP はそれぞれ高圧， 中圧, 低圧を示し，1SH，2SH，1RH，2RH，EVA， 1ECO, 2ECO はそれぞれ 1 段目過熱器, 2 段目過熱器, 1 段目再熱器, 2 段目再熱器, 蒸発器, 1 段目節炭器, 2段目節炭器を示す）。これら図が示すように，回転 機器では低中圧タービンの低下が著しく, HRSG 各伝 熱面の性能にも低下が見られた. また，これら機器性 能のほかに，主蒸気配管での熱損失，HRSG ガス側の 圧力損失の上昇も確認された。

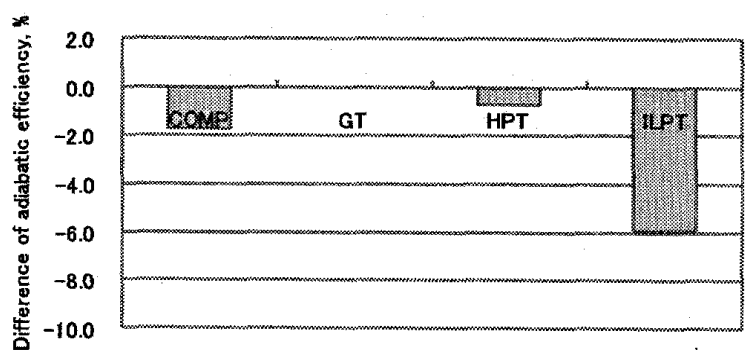

Fig. 18 Difference of adiabatic efficiency of each machine for 4 years 


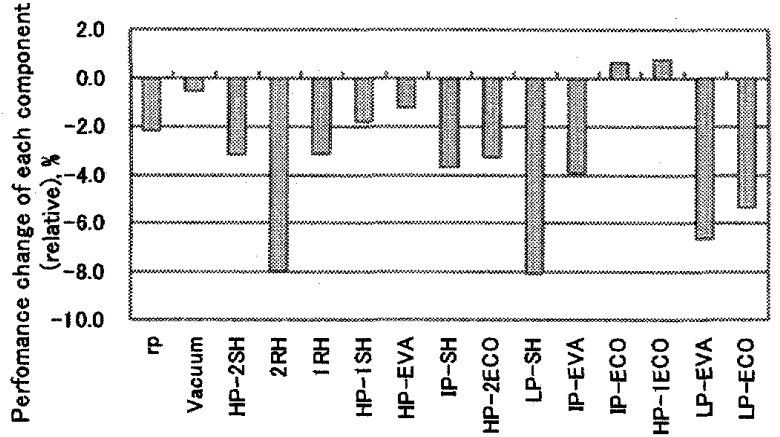

Fig. 19 Performance change of each component for 4 years

以上のように，実測値基淮解析により機器個别の性 能の変化が把握できたが, 特に GTCC 発電プラントに おいては汽力発電プラントに比へ機器の種類が多く, 機器によってその性能指標が異なる. そこで, プラン 卜熱効率の低下の主要因を特定するため, 機器性能基 準解析によってこれらの因子がプラント熱効率に与え る影響を定量的に解析した. その結果を図 20 に示寸。 この図から, 本 GTCC 発電プラントの熱効率低下の主 要因はILPT 断熱効率の低下であり，その他，圧縮機 断熱効率の低下，復水器真空度の低下であることがわ かった. 一方で, HRSG 伝熱面の性能低下はほとんど プラント熱効率の低下には大きくは影響していないこ とがわかった.

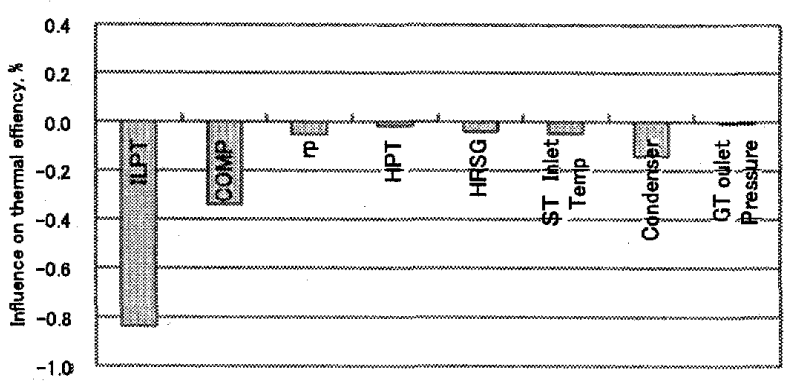

Fig. 20 Effect of each factor on thermal efficiency

以上の結果のように，本解析手法によって既設の汽 力ならびにGTCC発電プラントにおける熱効率低下要 因，さらにそれらの影響を定量的に把握できた。 した がって，本解析手法は，火力発電プラントの熱効率低 下主要因の特定に有効であると考える.

\section{4. 結 語}

火力発電プラントにおいて, プラント熱効率の維持, 向上のため, プラント熱効率が低下した場合，その要
因の特定が必要である．そこで，計測運転データを用 いた熱物質収支解析により熱効率影響因子を把握し， また, 外的条件変化の影響を排除した上で, 個々の因 子がプラント熱効率に与える影響を定量化することに より，熱効率低下要因の解明を行う手法を開発した. さらに，その手法を用いて既設の汽力および GTCC 発 電プラントの熱効率低下要因の解明を行い，本手法が これらに対して有効であることを示した.

\section{謝辞}

本手法の開発にあたっては，電力各社の方々から， 火力発電所の現場における熱効率管理の現状や要望に ついてご教授いただいた．また，実際の解析研究を通 じて, 電力各社の方々には多くのご指導, ご鞭撻をい ただいた。ここに，関係各位に心から謝意を表す。

\section{文献}

(1) Japanese Industrial Standard, Land boilers - Heat balancing, B 8222:1993

(2) Japanese Industrial Standard, Steam turbines acceptance test, B 8102:2002

(3) Koda, E., Takahashi, T., "Method of systems analysis, analyzation equipment using it and recording medium who can read computer that records systems analysis program", Japanese Patent Disclosure H1 1-275340 (1999)

(4) Koda, E., Takahashi, T., Development of general purpose software to analyze the steady state of power generation systems, Energy Conversion and Management journal, Vol.43 (1999), pp. 264-268.

(5) Takahashi, T., Koda, E. and Mimaki, T., A Systematic Analysis of the Effect of Air Humidification to Gas Turbine System, International Journal of the Japan Society of Mechanical Engineers, Series B, Vol.45, No.3 (2002), pp. 530-535.

(6) Koda, E., Takahashi, T., Uematsu, K, Yamashita. K. Study on the High Efficiency Closed-Cycle Gas Turbine System for $\mathrm{CO}_{2}$ Collection, Journal of Gas Turbine Society of Japan, Vol. 30 No. 1, (2002), pp. 63-67.

(7) The Institute of Electrical Engineers of Japan ed., Thermal Power Generation (in Japanese), p.40, Ohmsha, Ltd.

(8) Thermal and Nuclear Power Engineering Society ed., Combined Generation (in Japanese), p.31, Thermal and Nuclear Power Engineering Society

(9) Umezawa, S., Performance Diagnosis using Optical Torque Sensor for Selection of a Steam Supply Plant among Advanced Combined Cycle Power Plants, JSME Journal of Power and Energy Systems, Vol. 2 (2008), No. 3 pp. 956-964. 